\title{
MASALAH SEKITAR PENERAPAN “ACT OF STATE DOCTRINE" OLEH PEJABAT NEGARA
}

\author{
Oleh \\ W.M. Herry Susilowati
}

Negara merdeka memiliki kedaulatan rakyat yang berakibat negara tersebut tidak dapat dihadapkan pada pengadilan negara lain sebagaimana teor imumias. Namun dalam perkembangannya teori imunitas absolut ternyata tidak dipertahankan lagi secura ketat. kemudian muncul teori imunitas sekunder atau "Act of State Doctrine" yang terkenal dalam bidang Hukum Perdata Internasional Negara hanya akan mendapat imunitas kedaulatannya jika ia bertındak dalam kapasitas sebagat suatu negara (dalcm status "iure imperi" dan dalam melakukan tindakan sebagai "Public Act"). Perlindungan tidak diberikan jika negara berada dalam status "iure gestionis" dan melakukan tindakan sebagai pedagang "Commerciil Act". Dalam perkemhangannya "Act of State Doctrine" telah mengalami pembatasan dengan adanya "Foreign Sovereign Immunity Act" tahun 1976, dimana sangat dimungkinkan negara maupun pejabat yang bertindak mewakili negara dapat digugat dihadapan pengadilan negara asing; karena kekebalan bukan lagt suatu "absolut immunity" melainkan hanva "restrictive immunity"

\section{Pendahuluan}

Dimilikinya kedaulatan rakyat oleh negara merdeka, membawa konsekuensi bahwa negara tidak dapat dihadapkan pada pengadilan negara lain, karena negara berdaulat kedudukannya sama dengan negara berdaulat lainnya. Inilah teori imunitas, sesuai dengan adagium "par imparem non habet jurisdiction" bahwa negara yang berdaulat tidak dapat menerapkan yurisdiksinya terhadap negara berdaulat lainnya, tetapi hanya boleh menerapkan yurisdiksinya atas batas-batas atau pribadi-pribadi yang kedudukannya lebih rendah dari pada negara itu.

Perkembangan dari praktek negaranegara (yurisprudensi pengadilan) membuktikan bahwa teori imunitas absolut ternyata sudah tidak dipertahankan lagi secara ketat. Disana-sini terjadi pengurangan terhadap nilai dari kedaulatan suatu negara dalam hubung̨annya dengan negara berdaulat lainnya Hal ini disebabkan sehubungan dengan diterapkannya beberapa peraturan perundang-undangan suatu regara nasional dalam praktek hubungan antar negara terutama dalam masalah-masalah yang menyangkut hukum perdata, jika timbul sengketa antara pihak swasti asing dengan negara berdaulat yang menyebabkan pihak swasta asing tersebut mencierita kerugian yang diakibatkan oleh negara tersebut. Apakah dalam hal ini negara dapat digugat di pengadilan dari negara asing tersebut? 
Inilah masalah tentang teori imunitas kedaulatan.

Dalam yurisprudensi berbagai negara, hal itu sudah dijelaskan; bahwa perlindungan terhadap sesuatu negara dalam bentuk imunitas kedaulatannya, hanya diberikan apabila negara bersangkutan telah bertindak dalam kapasitasnya sebagai suatu negara, sebagai suatu kekuatan politis dan tidak sebagai suatu pedagang. Dengan perkataan lain, negara dalam status "iure imperii" dan melakukan suatu "Public ACt". Perlindungan tidak diberikan oleh suatu negara asing terhadap suatu kepentingan negara nasional, apabila negara nasional tersebut berada dalam status "nure gestionis", yaitu negara sebagai suatu pedagang yang melakukan suatu "Commerciil Act" (Sudargo Gautama, 1980:14).

Selanjutnya terhadap tindakantindakan negara yang berdaulat yang diakui oleh negara sang hakim, maka sebagai negara yang merdeka tidak dapat diuji oleh pihak hakim asing sepanjang negara tersebut berstatus tetap sebagai "iure "imperii". Inilah yang disebut teori imunitas secara sekunder atau " $\mathrm{ACt}$ of State Doctrine" yang terkenal dalam bidang hukum perdata Internasional.

Di dalam "Act of State" , negara bisa bertindak ataupun berstatus iure imperii ataupun iure gestionis, hanya untuk "Act of State Doctrine" disyaratkan negara harus berstatus sebagai iure imperii. Oleh karena itu, maka hakim pengadilan asing harus bisa membuktikan terlebih dahulu adanya status iure gestionis, jika akan mengadili negara asing. Jadi "Act of State Doctrine" tidak berlaku terhadap tindakantindakan negara yang termasuk "Commercil Act".

Pada dasarnya pemerintah sebagai badan kelengkapan negara dalam negara kesejahteraan (welfare state) tidak hanya melaksanakan Undang-undang saja, tetapi atas dasar "freies Ermessen" dapat melakukan perbuatan-perbuatan lainnya meskipun belum diatur secara tegas oleh Undang-undang. Oleh karenanya, negara dalam tindakannya (pejabatnya) untuk menerapkan "Act of State Doctrine", dimungkinkan terjadinya penyalahgunaan wewenang (de tournement de pouvoir) yang dilakukan oleh pejabat negara tersebut. Di samping itu, akhir-akhir ini lebih banyak negara turut serta dalam perdagangan, sehingga status negara dalam hal ini adalah sebagai pedagang (iure gestionis) yang melakukan Commerciil Act.

Dari hal tersebut di atas, yang menjadi masalah adalah:

Apakah tindakan pemerintah sebagai badan kelengkapan negara berdaulat dalam menerapkan "Act of State Doctrine" dapat digugat dihadapan forum negara asing? dan apakah tindakannya tersebut dapat dilindungi oleh imunitas negara atau tidak?

Penulis hanya membahas " $\mathrm{Act}$ of State Doctrine" saja, karena membahas "Act of State Doctrine" termasuk juga membahas imunitas kedaulatan (kedaulatan 
primer), di samping itu masalah sekitar "Act of State Doctrine" telah mengalami banyak perkembangan yang perlu selalu diketahui, sebab dipandang sebagai doktrin tentang cara pengadilan menahan diri untuk menggugat negara berdaulat

\section{Batasan "Act of State Doctrine"}

Negara berdaulat tidak dapat mengklaim yurisdiksi atas negara berdaulat lainnya, termasuk juga terhadap tindakantindakan negara berdaulat lainnya. Inilah teori "Act of State Doctrine" atau "Secondary Immunity" yang terkenal dalam Hukum Perdata Internasional (HPI). Menurut kaedah HPI, maka sahnya sesuatu perbuatan lazimnya ditentukan oleh hukum dari tempat dimana perbuatan itu dilakukan. Perbuatan dari suatu pemerintah yang berkuasa di dalam wilayah negaranya sendiri, oleh karena itu harus dianggap adalah hukum yang berlaku pada tempat itu, jadi hukum daripada negara yang berangkutan. (Sudargo Gautama, 1980:13).

Namun ternyata kemudian dalam perkembangannya, kaedah HPI yang menjadi dasar daripada "Act of State Doctrine" ini telah mendapat perubahanperubahan tertentu, dengan perkataan lain, bahwa sekalipun suatu perbuatan dianggap sah di tempat dimana terjadi perbuatan itu namun dapat dipandang oleh negara-negara asing tertentu sebagai bertentangan dengan hukum yang berlaku di negaranya. (Yudha Bhakti, 1982:21).

Dengan demikian, maka persoalan pokok adalah mengenai apakah tindakan dari suatu negara yang berdaulat yang didasarkan atas suatu peraturan hukum nasional negara tersebut dapat diuji oleh hakim dari negara lain.

Doktrin itu didasarkan atas "Trias Politika" atau "Separation of Powers" yang dianut oleh Amerika Serikat. Pihak yudikatif menganggap tidak berwenang untuk turut campur dalam bidangnya pihak eksekutif. Jadi apabila suatu pemerintah sudah diakui oleh pihak eksekutif sebagai pemerintah yang sah dan berdaulat, maka pihak yudikatif tidak akan mengujinya lebih lanjut dan menerima hal demikian. (Sudargo Gautama, 1980:11).

Dalam melakukan tindakannya, negara dapat digolongkan dalam status iure imperii dan dalam status iure gestionis. Negara hanya dapat mengklaim imunitas apabila bertindak sebagai suatu negara dan terhadap "Act of State Doctrine" ada pengecualian yaitu bahwa tidak akan diberlakukan ketentuan tersebut, apabila negara tersebut ditinjau dar perbuatannya itu telah melakukan suatu tindakan usaha komersiil belaka (iure gestionis). (Sudargo Gautama, 1980:17). Dengan demikian kalau negara berstatus sebagai iure imperii berlakulah "Act of State Doctrine". Negara dikatakan berstatus sebagai iure imperii, apabila negara yang bersangkutan telah bertindak dalam kapasitasnya sebagai suatu negara (sebagai suatu kesatuan politis) yang dihadapkan kepada Pengadilan Asing.

Apa kriteria negara berstatus "iure imperii"? 
Dalam hal ini dapat diambil kasus menarik sekitar pencabutan Hak Pengusahaan Hutan (HPH) untuk pengolahan eksploitasi hutan di Kalimantan antara Industrial Investment Development (iorporation, Indonesia Industrial Investment Corporation Ltd., dan Forest Product (orporation Ltd., adalah kelompok penggugat yang berhadapan dengan Multinational ( orporation Mitsui \& Co. Ltd. dan Mitsut \& $\quad(0 . \quad(L / S A)$ Inc. sebagai tergugat dihadapan Unted District Court for the Southern District of Texas, yang diminta adalah penggantian kerugian berdasarkan Anti-Trust Law America, yaitu Sherman $A c t$, karena adanya pelanggaranpelanggaran yaitu praktek-praktek Anti Competitive, berkenaan dengan operasi kehutanan penebangan kayu dan sebagainya di Kalimantan.

Dalam peradilan tingkat pertama tersebut tergugat dinyatakan tidak dapat dituntut berdasarkan eksepsi "Act of State Doctrine", tetapi kemudian pada tingkat banding keputusan dari Distric Court dibatalkan serta diperintahkan agar supaya dilanjutkan perkara itu; karena kerugian yang disebabkan oleh tindakan tergugat ini berdasarkan perbuatan-perbuatan dari pihak tergugat yang dalam suatu komplotan tertentu, secara kerjasama, telah mengadakan tindakan-tindakan penghalang kompetisi yang bebas, sehingga karena tindakan-tindakan inilah telah lahir penolakan $\mathrm{HPH}$ oleh Pemerintah Indonesia. Penggugat telah mengajukan 3 (tiga) masalah dasar untuk mengemukakan bahwa "Act of State Doctrine" tidak dapat diperlukan, yaitu sebagai berikut:

1. Para penggugat telah mengalami kerugian karena tindakan-tindakan dari para tergugat dan bukan oleh tindakantindakan dari Pemerintah Indonesia;

2. Para tergugat tidak dapat mengelakkan tanggung jawab untuk. penggantian kerugian disebabkan oleh karena perbuatan mereka sendiri yang tercela, perbuatan-perbuatan mana harus dilihat secara sendiri dan terpisah walaupun perbuatan-perbuatan dari pemerintah RI menambah pada keruggian yang telah diderita oleh para penggugat;

3. Sehingga diberikannya Hak Pengusahaan Hutan kepada Penggugat (Joint Venture) oleh pihak pemerintah RI dapat dianggap bukan suatu tindakan "sebagai pemerintah", tetapi lebih dapat dilihat seperti membuat suatu perjanjian tertentu dalam melakukan Forestry Agrement dengan Joint Venture bersangkutan. (Sudargo Gautama, 1980;12-13).

Negara yang berdaulat harus menghormati kemerdekaan dari negara berdaulat lainnya dan pengadilanpengadilan dari suatu negara tidak dapat menjadi hakim untuk mengadili perbuatanperbuatan dari pemerintah-pemerintah lain yang telah dilakukan di clalam wilayah negara itu atau dengan perkataan lain negara berdaulat dalam status iure imperi tidak dapat digugat dihadapan forum hakim negara lain Yang menjadi pertanyaan 
selanjutnya adalah: "Apakah yang dapat dilakukan oleh orang yang telah menjadi korban perbuatan-perbuatan melanggar hukum dari suatu negara berdaulat?". Jika orang bersangkutan secara pribadi menggugat negara berdaulat tersebut, jelas tidak mungkin berhasil; tetapi orang tersebut dapat mengajukan persoalannya melalui pihak eksekutifnya dengan menggunakan saluran diplomatik atau melalui Mahkamah Internasional atau juga dapat melalui Internasional Centre for the Settlement of Investment Disputes (ICSID)) dari World Bank.

Berdasarkan pada praktek-praktek di Amerika Serikat dan Inggris ternyata bahwa untuk menentukan iure imperii dan iure gestionis tidak mudah walaupun telah diatur dalam Undang-undang tentang imunitas kedaulatan bagi negara asing di forum pengadilan, seringkali pihak pengadilan menanyakan lebih lanjut kepada pihak eksekutif.

Perkembangan dalam yurisprudensi Amerika Serikat dari dulu sampai sekarang ternyata memperlemah berlakunya "Act of State Doctrine" ini dengan adanya berbagai pembatasan dan penentuan mengenai segala sesuatu tidak lagi diserahkan semata-mata kepada pihak eksekutif, melainkan telah dikatakan bahwa sekarang pihak pengadilan sendirilah yang harus menentukan. (Sudargo Gautama, 1980:62).

Seperti yang telah disinggung di atas bahwa salah satu kriteria dari pembedaan antara iure imperii dan iure gestionis adalah terletak pada kriteria "Commerciil Act", di samping itu kriteria lainnya adalah terletak pada fungsi organisasi negara dalam melakukan tindakannya. Dengan perkataan lain, bahwa sekalipun tindakan tersebut dalam kriteria umum termasuk tindakan perdata, namun apabila tindakan tersebut dilakukan dalam rangka menjalankan fungsi negara, maka tindakan tersebut masih tetap dalam kerangka iure imperii. (Yudha Bhakti, 1982:84).

Di Amerika Serikat dengan adanya "Foreigh Sovereign Immunities Act" tahun 1976, telah terjadi pembatasan terhadap imunitas kedaulatan yaitu diterimanya teori "Restrictive Immunity" yang tidak membenarkan diberikannya imunitas kedaulatan terhadap negara yang melakukan (ommerciil Act, iure gestionis. Dengan demikian negara yang melakukan perbuatan komersiil saja yang dapat digugat dihadapan Pengadilan Amerika Serikat. "Foreign Sovereign Immunities Act" tersebut mengutamakan prinsip teritorialitas yakni wilayah Amerika Serikat sendiri, di samping itu jika dilakukan di luar wilayah Amerika Serikat namun dapat berakibat langsung di Amerika Serikat dalam muatan komersiil, maka tidak ada lagi imunitas kedaulatan.

Pemerintah RI sampai saat ini belum membuat peraturan perundangundangan tentang imunitas kedaulatan seperti yang dimilliki oleh Amerika Serikat. Oleh karena itu, sudah saatnya untuk segera disusun peraturan perundang- 
undangan yang mengatur secara rinci tentang pelaksanaan imunitas kedaulatan sesuai dengan pandangan hidup bangsa Indonesia dan juga mendasarkan pada Hukum Internasional yang bersifat hukum alam.

\section{Negara Dan Pejabatnya Dalam Penerapan "Act of State Doctrine"}

Negara dalam melaksanakan tindakannya (dalam status iure imperii) diwakili oleh badan-badan kelengkapan negara, negara yang melakukan tindakan tersebut merupakan bagian integral dari pelaksanaan fungsi-fungsi negara berdaulat. Dalam tulisan ini badan kelengkapan negara hanya dibatasi pengertiannya pada pejabat negara pemegang jabatan negara (politieke ambtsdrager) yang berdasarkan Penjelasan Pasal 11 UU No.8 Tahun 1974, yaitu:
mulota1. Presiden
2. Anggota Permusyawaratan/Perwakilan Rakyat

3. Anggota Badan Pemeriksa Keuangan

4. Ketua, Wakil Ketua, Ketua Muda dan Hakim Agung

5. Anggota Dewan Pertimbangan Agung

6. Menteri

7. Kepala Perwakilan RI di luar negeri yang berkedudukan sebagai duta bear luar biasa dan berkuasa penuh

8. Gubernur Kepala Daerah

\section{(xomein 9. Bupati \\ i5 Xitraton Daerah/Walikotamadya Kepala \\ Daerah \\ 10. Pejabat lain yang ditetapkan dengan peraturan perundang- undangan.}

Administrasi Negara adalah gabungan jabatan yang berada di bawah pimpinan pemerintah yang melakukan sebagian pekerjaan pemerintah yakni tugas menyelenggarakan kesejahteraan umum (Bestuurzorg), termasuk dalam pengertian ini adalah juga pejabatnya.

imu Dalam melaksanakan aktivitasnya, administrasi negara memerlukan kebebasan yaitu kebebasan untuk dapat bertindak atas inisiatif sendiri, terutama dalam menyelesaikan soal-soal genting yang timbul sekonyong-konyong dan yang peraturan penyelesaiannya belum ada, yahg belum dibuat oleh badan-badan kenegaraan yang diserahi tugas legislatif, terkenal dengan nama fries Frmessen (dalam Bahasa Jerman) atau ( Pouvoir Discretionnaire (Diskrest) (Dalam Bahasa Perancis).

Aurn Tindakan administrasi sis negara tersebut dapat dibedakan dalam 2 (dua) golongan, yaitu:

a. Golongan perbuatan hukum (yuridis), yang dibagi lagi dalam perbuatan hukum privat dan perbuatan hukum publik.

b. Golongan perbuatan yang bukan perbuatan hukum (non yuridis). 
Dalam lapangan hukum administrasi negara, hukum privat tidak termasuk di dalamnya, sehingga yang diuraikan dalam makalah ini hanyalah perbuatan hukum publik.

Perbuatan hukum publik dibedakan dalam 2 (dua) segi, yaitu:

1. perbuatan hukum bersegi dua

2. perbuatan hukum bersegi satu.

Untuk perbuatan hukum publik bersegi dua ada yang berpendapat tidak ada, karena tidak ada perjanjian yang diatur oleh hukum publik; namun menurut Van der Pot, Van Pragg, Kranenberg, Vegting, Wiarda dan Donner, ada perbuatan hukum publik yang bersegi dua, yakni perjanjian menurut hukum publik, misalnya Perjanjian Kerja Jangka Pendek yang diadakan oleh seorang pekerja swata dengan Pemerintah untuk waktu 3 (tiga) tahun. Adapun perbuatan hukum publik bersegi satu yang dilakukan oleh alat-alat pemerintahan berdasarkan suatu wewenang istimewa dinamakan sir beschiking (ketetapan).

Dalam melaksanakan kebebasan bertindaknya pejabat administrator negara, bisa terjadi melanggar hukum. Mahkamah Agung melalui Surat Edaran Mahkamah Agung tanggal 25 Pebruari 1977 No.MA/Pemb.?0159/77 dan mengulangi lagi rumusan akhir lokakarya "Pembangunan Hukum Melalui Peradilan", tanggal 30 Mei - 1 Juni 1977 di Lembang. merumuskan kriteria rechmatigheid (keabsahan) tindakan penguasa adalah:
1. Undang-undang dan peraturan formal yang berlaku;

2. kepatutan dalam masyarakat yang harus dipatuhi oleh penguasa;

3. perbuatan kebijaksanaan penguasa tidak termasuk kompetensi pengadilan untuk menilainya, kecuali ada unsur "willekeur" dan "detournement de pouvoir". (Philipus M. Hadjon, et.al., 1993:306-307).

ad. 1). Kriteria pertama "rechmatigheid" tindakan penguasa menurut Mahkamah Agung adalah Undangundang dan peraturan formal yang berlaku;

Kriteria ini mengandung elemen yang sangat legalistik, mengingatkan kita pada pendirian Hoge Raad di Belanda sebelum tahun 1919 yang berpegang pada "wet" sebagai satu-satunya ukuran rechmatigheid, sehingga "onrechmatig" stos berarti "onwetmatig" dan kalau ditarik lebih akan masuk ke dalam konsep rechsstaat yang sempit, yaitu "wettenstaat" (negara undangundang). Dan dengan kriterium ini hakim hanyalah "bouche de la lois". 
Ad.2). Kepatutan yang harus diperhatikan oleh Penguasa;

Kriteria kedua adalah "kepatutan yang harus diperhatikan oleh penguasa".

Apakah makna dan isi "kepatutan"?

Dalam Surat Edaran Mahkamah Agung tanggal 25 Pebruari 1977 No. MA/Pemb/0159/77

diinstruksikan kepada Ketua

Pengadilan Negeri dan Ketua

Pengadilan Tinggi di seluruh

Indonesia, "agar ... dalam

mengadili perkara dimana

Pemerintah digugat melakukan

perbuatan melanggar hukum,

hendaknya mengadakan

keseimbangan antara perlindungan terhadap perseorangan (individu) dan terhadap kepentingan persekutuan seperti penguasa ...". Apakah ini yang dimaksudkan dengan kepatuhan dalam masyarakat yang harus diperhatikan oleh penguasa. Berdasarkan penjabaran tersebut terkandung juga pengertian doelmatieg (berdasarkan tujuannya)

ad. 3). Perbuatan Kebijaksanaan Penguasa; Mahkamah Agung menegaskan bahwa perbuatan kebijaksanaan penguasa tidak termasuk kompetensi pengadilan untuk menilainya. Dalam rumusan akhir lokakarya tahun 1977 ditambahkan: "kecuali ada unsur "willekeur" dan "detournement de pouvoir"
Kebijaksanaan, negara selama ia bertindak sebagai iure imperii, akan tetapi tidak ada kekebalan kalau ia berstatus sebagai iure gestionis.

Berdasarkan pada analogi kriteria rechmatigheid tersebut terhadap tindakan pejabat negara yang dapat dan tidak dapat diganggu gugat; dalam penerapan " $\mathrm{Act}$ of State Doctrine" terdapat kesamaan bahwa pejabat negara dalam melaksanakan doktrin tersebut juga dapat digugat secara sendiri, karena terdapatnya unsur tindakan komersiil yang tidak mendapatkan kekebalan kedaulatan lagi.

Terhadap segala tindakan pejabat negara tersebut berlaku asas praduga rechmatig (vermoeden van rechmatigheid praesumtio causa), yakni bahwa setiap tindakan penguasa selalu harus dianggap rechmatig sampai ada pembatalannya karena sesuai dengan hukumnya.

Demikian juga terhadap negara dalam "Act of State Doctrine", tetaplah terdapat kekebalan padanya sampai terbukti bahwa tindakannya tersebut adalah bukan sebagai negara (kesatuan politik) tetapi sebagai pedagang (Commerciil Act) yang akan hilang imunitas kedaulatannya, sehingga dapat digugat $\mathrm{di}$ forum pengadilan asing yang dirugikan oleh tindakan tersebut.

\section{Penutup}

Berdasarkan uraian tersebut, maka dapat disimpulkan sebagai berikut:

Bahwa pada awalnya negara berdaulat tidak dapat digugat dihadapan 
forum pengadilan asing, namun di lain pihak "Act of State Doctrine" pada dasarnya yang merupakan eksepsi, negara atau pejabat yang mewakilinya dapat digugat oleh negara yang dirugikan oleh tindakan negara tersebut di forum pengadilan asing, selama dapat dibuktikan bahwa tindakan negara tergugat tersebut adalah tindakan berdagang. Dalam praktek pengadilan di Amerika Serikat dan Inggris, doktrin ini dipandang sebagai doktrin tentang cara pengadilan menahan diri.

Dalam perkembangannya "Act of State Doctrine" telah mengalami pembatasan-pembatasan, yakni dengan adanya "Foreign Sovereign Immunity Act" tahun 1976 yang kemudian kekebalan kedaulatan bukan lagi suatu "absolut immunity" melainkan hanya "restrictive immunity", yakni bahwa "Act of State Doctrine" hanya diberikan jika negara bertindak sebagai kesatuan politik dan pejabat negara yang melaksanakannya hanya bertindak dalam kriteria rechmatigheid. "Act of State Doctrine" hanya diberlakukan manakala negara bertindak sebagai kesatuan politik iure imperii, demikian juga terhadap pejabat negara yang bertindak mewakili negara untuk melaksanakan tindakan ini dapat dituntut di forum pengadilan negara asing. Selanjutnya dengan semakin banyaknya tindakan negara dan keterlibatan negara RI dalam beberapa perkara di luar negeri yang berhubungan dengan "Act of State Doctrine", maka penting bagi kita untuk selalu memperhatikan perkembangan penerapan doktrin ini; dan dipandang sangat penting untuk bisa segera disusun Undang-undang yang mengatur tentang imunitas kedaulatan.

\section{DAFTAR PUSTAKA}

\section{J.G. Starke, Pengantar Hukum Internasional (I), Aksara Persada Indonesia, Jakarta, 1989.}

Mochtar Kusumaatmadja, Pengantar Hukum Internasional, Buku I Bagian Umum, Bina Cipta, Bandung, 1987.

Sudikno Mertokusumo, Mengenal Hukum (Suatu Pengantar), Liberty, Yogyakarta, 1988.

\section{Sudargo Gautama, Hukum Perdata dan} Dagang Internasional, Alumni, Bandung, 1980.

\section{- Pengertian Tentang} Negara Hukum, Alumni, Bandung, 1983

\section{- Aneka Masalah Hukum Perdata Internasional, Alumni, Bandung, 1985.}

Philipus M. Hadjon, Pengantar Hukum Administrasi Indonesia, Gadjah Mada University Press, Yogyakarta, 1983. 
Yudha Bhakti A, Penerapan "Sovereign Immunity" dan "Act of State Doctrine" Negara Berdaulat Dihadapan Forum Pengadilan Asing, Tesis, Perpustakaan UNPAD, Bandung, 1982. 